\title{
Laboratory Diagnosis of CMV Infection: A Review
}

\author{
Munira Jahan ${ }^{1}$
}

${ }^{1}$ Department of Virology, BSMMU;

A diagnosis of CMV disease is much more difficult to establish, as patients may excrete the virus in urine, semen, or cervical secretions for years following its acquisition. Thus, a positive cultures from these sites does not, by itself, prove that CMV is the cause of the patient's current symptoms. Although recovery of the virus or detection of CMV antigen from the blood or tissues is suggestive of active disease due to CMV. The diagnosis of CMV infection can be substantiated by one or more of the following : 1) electron microscopic detection of typical CMV virion, 2) histologic or Cytologic detection of typical CMV cytopathology, 3) Isolation of Virus, 4) detection of CMV antigen in blood and tissues, 5) detection of CMV genome in tissues, 6) DNA amplification, 7) serology

\section{Inroduction}

It is difficult to diagnose CMV infection in immunocompromised patients as it requires not only detection of virus but also determining whether CMV is causing disease. CMV shedding and viremia are common in patients with impaired cellular immunity even when disease due to CMV is not present. In addition, preventive and therapeutic options are few and not completely effective. The severity of CMV infection are roughly parallel with the degree of immunosuppression. Although immunocompromised patients are at risk for morbidity due to wide variety of pathogens, few, if any of these are capable of producing such widspread disease as CMV. CMV-related morbidity follow a progressive, relentless course in the absence of effective therapeutic intervention. Thus, rapid diagnosis of active CMV infection is of great importance to avoid over treatment with immunosuppressive drugs and to guide antiviral therapy. In recent years, treatment of CMV

\footnotetext{
Correspondence:

Dr. Munira Jahan

Assistant Professor

Department of Virology

BSMMU

Tel No: 8617099, 0171527700

E-mail : mjahan1970@yahoo.com
}

infection in high-risk patients prior to the onset of clinical disease is preferred ${ }^{1,2}$.

Since rapid and sensitive technique for diagnosis of CMV infection is of vital importance for the management of immunocompromised patients, a number of rapid and sensitive virus detection methods have been developed. These includes DNA probe techniques ${ }^{3}$, Polymerase chain reaction (PCR) 4,5, CMV antigen detection in biopsies and bronchoalveolar lavage 6,7 , and immunofluorescence technique for detection of CMV early antigens in cell ${ }^{7-, 10}$. Moreover, an assay has recently been developed for CMV antigenemia based on the detection of CMV immediate early antigen $\left(\mathrm{pp}^{65}\right)$ in circulating leucocytes ${ }^{1,10-12}$.

\section{Electron microscopy}

Electron microscopy has been used to identify CMV in urine and is $25 \%-95 \%$ as sensitive as viral culture in congenitally infected infants 13,14. Monplaisir 14 (1972) used ultracentrifugation, whereas Lee et al ${ }^{13}$ (1978) used a simpler, pseudoreplica technique. This method was $95 \%$ sensitive when the viral infectivity titer was $10^{4} / \mathrm{ml}^{13}$. Below this titer the sensitivity of the technique was only $25 \%$. Since many infants $>6$ months old and adults (especially those who are immunocompetent) have titer $>10^{4} / \mathrm{ml}$, the use of electron microscopy is limited. Electron microscopy is now rarely employed to identify CMV in clinical virology laboratories.

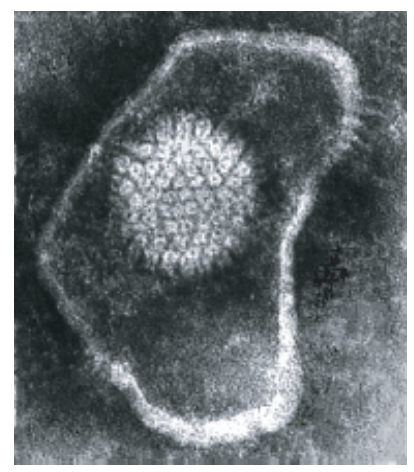

Figure 1: Electron micrograph of Cytomegalovirus 


\section{Cytology/ Histology}

Cytologic technique may be applied in an attempt to find characteristics intranuclear inclusions in specimens. Inclusion-bearing cells may be found in saliva, milk. cervical and tracheal secretions, and in touch preparations from biopsy or necropsy tissues. The microscopic hallmark of CMV infection is the large (cytoplasmic) $25-35 \mu \mathrm{m}$ cell containing a large, central, basophilic intranuclear inclusion is referred to as "owl's eye" because it is separated from the nuclear membrane by a hallow. These inclusions are seen well with Papanicolaou or hematoxylin-eosin stains. Clusters of small intracytoplasmic inclusions may also be seen in CMV infected cells. These inclusions are best seen with WrightGiemsa Stains ${ }^{15}$. Sensitivity of the standard Cytologic techniques is low relative to virus isolation, irrespective of the type of specimen. Only $50 \%$ of the urine samples from infants with symptomatic congenital CMV infection are positive. Even with the use of monoclonal antibody, successful identification of infected neonates is only $50 \%{ }^{16}$. In addition, the presence of these cells in urine sediment is not pathognomonic of CMV. Histologic examination of a small piece of tissue obtained, e.g., by bronchoscopic lung biopsy is prone to sampling errors and to false-negative results and was only $75 \%$ as sensitive as immunofluorescence ${ }^{6}$.

\section{Isolation of Virus}

Isolation of $\mathrm{CMV}$ from a clinical specimen remains a definitive diagnostic procedure against which all newer assays must be compared. Traditionally, urine, blood, and throat specimens have been cultured, but during active infection a wide variety of specimens yield viruses. In most infected individuals urine contains moderate to large amounts of infectious virus particles and is a convenient and reliable specimen for culture. However, viruria often represents asymptomatic infection and can be prolonged (for months to years). Viremia, demonstrated by culture of leukocytes, correlates better with active disease, although many viremic individuals are also asymptomatic ${ }^{17}$.

Since CMV grows only in human diploids fibroblast cell cultures, specimens for isolation must be inoculated into cell lines such as WI-38, MA-184, or Flow 2000. The fundamental limitation of traditional isolation of virus is the prolonged interval required for development of visible cytopathology in cell cultures, which on average, takes 1-2 weeks. However when little virus is present in the specimen, recovery of virus can sometime take 6 weeks.

Important advances resulted from the development of monoclonal antibodies to the 72-KDa major immediate-early protein of CMV . These antibodies enable the detection of a nuclear antigen in fibroblasts within hours of infection, thus permitting the evaluation of cultures long before the appearance of identifiable cytopathology 18,19. Unlike conventional cultures, which are usually performed in tubes containing fibroblast monolayer, cultures intended for monoclonal antibody staining are performed on flat monolayers, either on cover slips in shell vials or in 24-well cluster plates. Centrifugation of monolayers greatly assists absorption of virus, thereby apparently increasing four fold infectivity of the viral inoculums ${ }^{18}$. Urine and bronchoalveolar lavage specimens have given the best results with the rapid culture techniques. The sensitivity has been reported to exceed that of conventional culture, probably because of the enhancement of infectivity provided by centrifugation 18,19. Antibodies to early and late CMV antigens are also useful for direct visualization of infected cells in clinical specimens. This has been demonstrated with bronchoalveolar lavage cells ${ }^{7}$, biopsy specimens ${ }^{6}$, and leucocytes ${ }^{10,12}$.

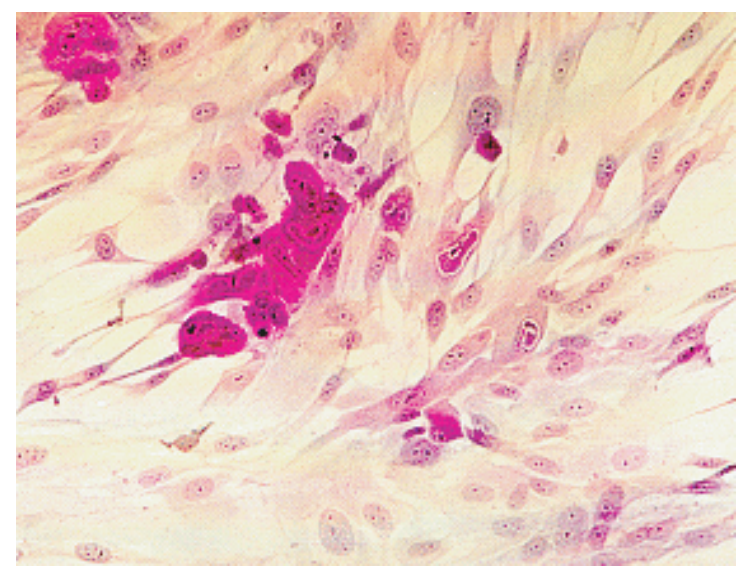

Figure 2: Cytopathic effect of CMV

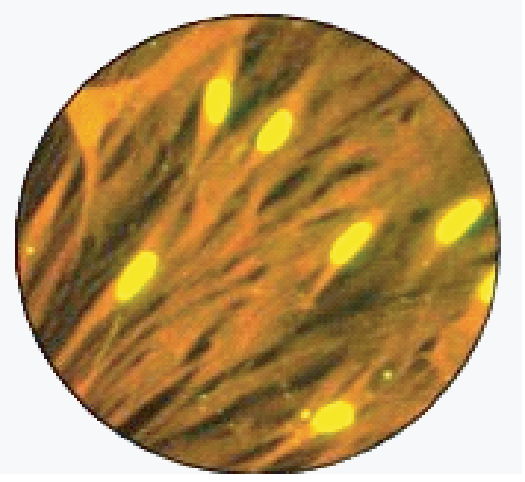

Figure 3: CMV centrifugation culture fixed and stained $16 \mathrm{hr}$ after inocculation showing viral protein in nuclei of infected human fibroblast cells

\section{Nucleic acid hybridization}

Methods that utilize the detection of CMV DNA directly or indirectly are now used regularly for diagnosis of CMV 
infection. In situ cytohybridization has been available for more than a decade and is currently able to detect single infected cells. Nevertheless in situ cytohybridization technology remains labour intensive, which limits its use except in the research setting. The use of DNA-DNA hybridization to detect $\mathrm{CMV}$ in clinical samples directly was first described by Chou and Merigan in $1983^{20}$. They used ultra centrifuged urine, immobilized the sample on nitrocellulose filters, and hybridized with a 32 P-labeled cloned probe. This cloned probe was prepared by digestion of CMV strain AD-169 by the restriction enzyme EcoRI. Although the test could be performed in 24 hours, sensitivity was very low. Out of 48 culture-positive sample 14 (29\%) were negative. Virtually all samples with titers $<500 \mathrm{cfu} / \mathrm{ml}$ were negative. No false positive results were obtained.

Investigators in other laboratories have reported improved sensitivity of nucleic acid hybridization on urine samples( $92 \%)$ but have also reported occasional positive results $(3 \%$ $12 \%$ ) in specimens that were culture negative ${ }^{3}$. On the basis of additional clinical and laboratory data, it was suggested that the cultures for the patients were false negative rather than that the hybridization assays were false positive ${ }^{3}$.

\section{Polymerase chain reaction}

CMV DNA PCR (Polymerase Chain Reaction) is a highly sensitive, rapid ( $6 \mathrm{hrs})$ technique based on selective amplification of specific nucleic acid sequences. The PCR assay is more versatile and can be used either qualitatively (diagnostic PCR) or quantitatively to measure the viral load, which is proportional to the level of CMV DNA. It was first developed as a sensitive methods for CMV detection. But because its ability to distinguish small DNA sequence differences, it can be used to differentiate strains of CMV by selective amplification of hypervariable regions of the viral genome. PCR has the advantage that it can be used to detect CMV DNA in samples other than White blood cell (WBC), such as whole blood, plasma, cerebrospinal fluid, or bronchoalveolar lavage fluid ${ }^{4,21}$. CMV DNA in plasma correlates with presence of CMV infection in BAL samples. CMV DNAemia is correlated with risk and severity of CMV disease in immunocompromised patients ${ }^{4,5}$. Rasmussen 22 (1999) demonstrated a direct relationship between the viral load as estimated by PCR and the risk for subsequent development of CMVD. With the PCR method CMV infection may be detected as early as two weeks before the onset of symptomatic CMVD. This advantage has given impetus to the preemptive therapy strategy for the prevention of CMVD in high-risk patients. More recently the quantitative plasma assay by real time PCR methods has been described and are becoming essential in the management of transplant recipients by defining the population at high risk for $\mathrm{CMV}$ disease that requires pre-emptive antiviral treatment. The major disadvantage of PCR is that its great sensitivity can detect low levels of CMV that are not always predictive of disease ${ }^{5}$. That is the increased analytical sensitivity of the PCR assay leads to a lower clinical specificity.

\section{Antigen detection}

PP-65 antigenemia test in which specific monoclonal antibodies are used to detect, a CMV matrix phosphoprotein known as pp-65 in leukocytes,. Since its initial description 10 , the $\mathrm{pp}^{65}$ antigenemia assay has represented a major breakthrough for the diagnosis of CMV infections. The test has several advantages from the clinical perspective, and also in terms of laboratory practices. Method of detection of $\mathrm{pp}^{65}$ is very fast, allowing viral detection after 4-5 hour of blood sampling. CMV antigen positive blood cells appeared 1-3 weeks on average nine days before serologic signs of active infection ${ }^{12}$. Thus detection of CMV $\mathrm{pp}^{65}$ antigens appeared to be earlier indicator of active infection than CMV IgM antibody ${ }^{10,12,23}$.

This assay is sensitive and specific and yields result within 5 hours ${ }^{10}$. In addition, the antigenemia assay is quantitative and has been useful for estimating the likelihood of disease progression, as well as for monitoring the response to therapy 1,23

In clinical practice this could be useful for the early diagnosis and early institution of antiviral therapy. Furthermore the declining phase of CMV antigenemia indicating good prognosis is to guide safe discontinuation of antiviral drugs which may have severe side effects ${ }^{1}$.

So $\mathrm{pp}^{65}$ antigen test is a valuable tool for the early diagnosis and monitoring of active CMV disease in immunocompromised patients. The quantitative nature of the antigenemia assay may give an estimate of viral load, and this may be useful for monitoring patients before, during, and after therapy ${ }^{24}$. Sequential $\mathrm{pp}^{65}$ antigenemia assay in the CMV antibody negative patients will allow early detection of primary CMV infection and in the CMV IgG antibody positive patients early reactivation of CMV and may allow the detection of important changes in the antigenemia level. Early positive or rising antigenemia levels may signal the onset of active CMV disease and allow early preemptive therapy to be initiated, particularly in transplant recipients ${ }^{24}$. Transplant recipients with clinical CMV infection treated with ganciclovir showed a rapid decline in antigenemia levels which paralleled clinical improvement ${ }^{25}$. A persistently high or rising level of antigenemia despite appropriate therapy may signal progressive CMV disease or the development of viral resistance 25,26 . 


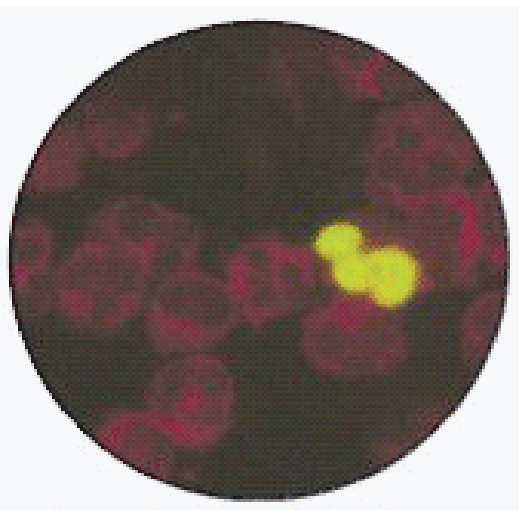

Figure $4 \mathrm{CMV} \mathrm{pp} 65$ antigens detected in nuclei of peripheral blood neutrophils

\section{Serology}

Two main reasons for the clinical use of serologic tests for CMV are for determining susceptibility to primary infection and for screening blood and therefore the potential for transmitting latent CMV. Seroconversion (seronegative to seropositive) remains a reliable means of diagnosing primary CMV infection but usually practical only for closely monitored patients such as transplant recipients, for whom pre and post infection sera are readily available.

Accuracy, speed and efficiency are important considerations in assaying for CMV antibody. Traditional CF technology does not fulfill any of these requirements very well, although its ability to detect seropositivity can be quite respectable when high-quality antigens are used 27,28 . More recently immunofluorescence, ELISA, Radioimmunoassay, indirect hemagglutination and latex agglutination assays have been used in many laboratories ${ }^{27,28,30}$. Each of these methods have potential advantage and pitfalls.

ELISA for detection of CMV antibody are available from several manufacturers. The ELISAs give higher antibody titers and is as accurate as CF assays in determining serologic status, are much easier to perform and eliminate the problem of anticomplimentary sera. Results are typically available in a few hours ${ }^{30-32}$.

Latex agglutination has become an important method of screening blood and organ donors for CMV antibody ${ }^{33,34}$. The assays provide results within minutes and is reasonably accurate despite its $\sim 5 \%$ rate of errors and a significant element of subjectivity in the reading of results ${ }^{33}$.

\section{Diagnostic methods for invasive CMV disease}

Immunocompromised patients have a high incidence of interstitial pneumonia with CMV as a major causative agent. In these patients bronchoalveolar lavage has become an accepted means of diagnosing pulmonary infections ${ }^{7}$.
Culture of lavage fluid, with overnight detection of immediate-early antigen, has proven to be more reliable than the culture of tissue obtained at biopsy in identifying CMV infection ${ }^{35}$. Support for a diagnosis of CMV hepatitis can be conveniently obtained by in situ hybridization with biopsy specimens ${ }^{36}$. Evidence of CMV infection has been obtained by in situ hybridization or antigen detection for a variety of other organs, including gastrointestinal mucosa ${ }^{37}$, and numerous other tissue specimens 38 in the disseminated CMV infection. CMV central nervous system disease can be diagnosed by DNA amplification ${ }^{21}$.

\section{References}

1. Boeckh MTA, Gooley D, Myerson T, Schoch CG, and Bowder RN. Cytomegalovirus $\mathrm{pp}^{65}$ antigenemia guided early treatment with ganciclovir at engraftment after allogeneic marrow transplantation : a randomized double blind study. Blood 1996; 88:4663-4071.

2. Grossi P S, Kusne C, Rinaldo K, George S, Maynone M, Rakela J, Fung J, and Starzl T E. Guidance of ganciclovir therapy with $\mathrm{pp}^{65}$ antigenemia in cytomegalovirus free recipients of liver from seropositive donors. Transplatation 1996; 61:16591660.

3. Spector DH, and Vacqier JP. Human cytomegalovirus (strain AD 169) contains sequences related to the avian retrovirus oncogene v-myc. Proc Natl Acad Sci USA 1983; 80: 3889-3893.

4. Gerna G, Zipeto D, Parea M, Revello M G, Silini E, Percivalle E, Zavattoni M, Grossi P, and Milanesi G. Monitoring of cytomegalovirus infections and ganciclovir treatment in heart transplant receipents by determination of viremia, antigenemia, and DNAemia. J Infect Dis 1991; 164: 488-498.

5. Zipeto D, Revello M G, Silini E, Parea M, Percivalle E, Zavattoni M, Milanesi G, and Gerna G. Development and Clinical significance of a diagnostic assay based on the PCR for detection of human CMV DNA in blood sample from immunocompromised patient. J Clin Microbiol 1992; 30:527-530

6. Hackman R C, Myerson D, Meyers J D, Shulman H M, Sale G E, Goldstein L C, Rastter M, Flournoy N, Thomas E D. Rapid diagnosis of cytomegaloviral pneumonia by tissue immunofluerescence with a murine monoclonal antibody. J Infect Dis 1985; 151: 325-329.

7. Emanuel D, Peppard J, Gold J, Armstrong D, Hamerling U. Rapid immunodiagnosis of cytomegalovirus pneumonia by bronchoalveolar lavage using human and murine monoclonal antibodies. Ann Intern Med 1986; 
104 : 476-481.

8. Gleaves CA, Smith TF, Schuster EA, Pearson GR. Rapid detection of cytomegalovirus in MRC-5 cells inoculated with urine specimens by using low sped centrifugation and monoclonal antibody to an early antigen. J Clin Microbiol 1984; 19: 917-919.

9. Schirm J, Timmerije W, Vander bij W, The TH, Wilterdink JB, Tegzess AM, Van son W J , Schroder F P. Rapid detection of infectious cytomegalovirus in blood with the aid of monoclonal antibodies. J Med Virol 1987; 23: $31-40$.

10. Vander Bij W, Torensma R, Vanson W, Anema J, Schirm J, Tegzess A M, and The T H. Rapid immunodiagnosis of active cytomegalovirus infection by monoclonal antibody staining of blood leucocytes. J Med Virol 1988b; 25: 179-188

11. Revello MG, Pereivalle E, Zauattoni M, Parea M, Grossi $\mathrm{P}$, and Gerna G. Detection of human cytomegalovirus immediate early antigen in leucocytes as a marker of viremia in immunocompromised patients. J med Virol 1989; 29:88-93.

12. Vander Bij W, Schirm J, Torensma R, Vanson W J, Tegzess A.M, and The T H. 1988a. The comparison between viremia and antigenemia for detection of cytomegalovirus in blood. J Clin Microbiol 26:25312535.

13. Lee FK, Nahmias A J, Stagno S. 1978. Rapid diagnosis of cytomegalovirus infection ininfants by electron microscopy. N Eng J Med 299 :1266-1270.

14. Montplaisir S, Belloncik S, Leduc NP, Onji PA, Martineau B, Kurstak E. Electron microscopy in the rapid diagnosis of cytomegalovirus: ultrastructural observation and comparison of methods of diagnosis. J Infect Dis 1972; 125: 533-538.

15. Shulman HM, Hackman RC, Sale GE, Meyers JD. Rapid Cytologic diagnosis of cytomegalovirus interstitial pneumonia on touch imprints from open lung biopsy. Am J Clin Pathol 1982; 77: 90-94.

16. Hanshaw J B. Congenital cytomegalovirus infection: A fifteen year perspective. J Infect Dis 1971; 123:555561.

17. Dummer JS, White LT, Ho M, Griffith BP, Hardesty RL, Bahnson HT. Morbidity of cytomegalovirus infection in recipient of heart or heart-lung transplants who received cyclosporine. J Infect Dis 1985; 152:1182-1191.

18. Gleaves CA, Smith TF, Schuster EA, Pearson G R. Comparison of standard tube and shell vial culture techniques for the detection of cytomegalovirus in clinical specimens. J Clin Microbiol 1985; 21: 217-221.

19. Paya CV, Wolt AD, Smith TF. Detection of cytomegalovirus infection in specimens other than urine by the shell vial assay and conventional tube cell culture. J Clin Microbiol 1987; 25:755-757.

20. Chou S, and Merigan TC. Rapid detection and quantitation of human cytomegalovirus in urine through DNA hybridization. N Eng J Med 1983; 308: 921-925.

21. Wolf DG, Spector SA. Diagnosis of human cytomegalovirus central nervous system disease in AIDS patients by DNA amplification from cerebrospinal fluid. J Infect Dis 1992;166:1412-1415.

22. Rasmussen L. Molecular pathogenesis of human cytomegalovirus infection. Transpl Infect Dis. 1999; 1(2):127-34

23. Landery M L, and Ferguson D. Comparison of quantitative cytomegalovirus with culture methods and correlation with clinical disease. J. Clin Microbiol, 1993; 31:2851-2856.

24. Van den Berg AP, Klompmaker IJ, Haagsma EB, SchltenSampson A, Bijleveld CMA, Schirm J, Van der Geissen $\mathrm{M}$, Slooff $\mathrm{MJH}$, and The TH. Antigenemia in the diagnosis and monitoring of active cytomegalovirus infection after liver transplantation. J Infect Dis 1991; 164: 265-270.

25. Mazzulli T, Rubin RH, Ferraro MJ, D'aquila RT, Doveikis SA, Smith BR, The TH, and Hirsch MS. Cytomegalovirus antigenemia: Clinical correlations in transplant recipients and in persons with AIDS. J Clin Microbiol 1993; 31 (10): 2824-2827.

26. Manfredi R, Lazzarotto T, Spezzacatena P, Monte PD, Mastroinni A, Coronado OV, and Chiodo F. Quantitative cytomegalovirus antigenemia during antiviral treatment of AIDS related CMV disease. J Antimicrob Chemo 1997; 40: 299-302.

27. O'Neill H J, Shirodaria P V, Connolly J H, Simpson D I $\mathrm{H}$, and McGeown M G. Cytomegalovirus -specific antibody responses in renal transplant patients with primary and recurrent CMV infections. J Med Virol 1988; 24:461-470.

28. Pass RF, Griffith PD, August A.M. Antibody response to cytomegalovirus after renal transplantation: Comparison of patients with primary and recurrent infections. J Infect Dis 1983; 147: 40-46.

29. Pass RF, August A M, Dworsky M E, Reynolds D W. 
Cytomegalovirus infection in a day care centre. N Eng $\mathrm{J}$ Med 1982; 307: 477-479.

30. Booth JC, Hannington G, Bakir TMF, Stern H, Kangro H, Griffith PD, Heath R B. Comparison of enzymelinked immunosorbent assay, radioimmunoassay, complement fixation, anticompliment immunofluorescence and passive haemagglutination techniques for detecting cytomegalovirus $\operatorname{IgG}$ antibody. J Clin Pathol 1982; 35: 1345-1348.

31. Schmitz H, Doerr H W, Kampa D, and Vogt A. Solidphase enzyme immunoassay for immunoglobulin $\mathrm{M}$ antibodies to cytomegalovirus. J Clin Microbiol 1977; 5: 629-634.

32. Yolken RH, and Leister FJ. Enzyme immunoassays for measurement of cytomegalovirus immunoglobulin $\mathrm{M}$ antibody. J Clin Microbiol 1981; 14: 427-432.

33. Adler SP, McVoy M, Biro VG, Britt WJ, Hider P, Marshall D. Detection of cytomegalovirus antibody with latex agglutination. J Clin Microbiol 1985; 22: $68-70$.

34. Chou S, and Scott KM. Latex agglutination and enzyme linked Immunosorbent assay for cytomegalovirus serologic screening of transplant donor and recipients. J Clinl Microbiol 1988; $26: 2116-2119$.

35. Crawford SW, Bowden RA, Hackman RC, Gleaves CA, Meyers J D, Clark J G. Rapid detection of cytomegalovirus pulmonary infection by bronchoalveolar lavage and centrifugation culture. Ann Intern Med 1988; $108:$ 180-185.

36. Naoumov NV, Alexander GJ, O'Grady JG, Sutherland S, Aldis P, Portmann BC, Williams R. Rapid diagnosis of cytomegalovirus infection in situ hybridization in liver grafts. Lancet 1988; 1: 1361-1364.

37. Robey SS, Gage W R, Kuhajda F P. Comparison of immunoperoxidase and DNA in situ hybridization techniques in the diagnosis of cytomegalovirus colitis. Am J Clin Pathol 1988; 89: 666-

38. Keh W C, and Gerber M A. In situ hybridization for cytomegalovirus DNA in AIDS patients. Am J Pathol 1988; 131: 490-496. 